\title{
Prevalence of Gryptosporidium spp. in Asymptomatic Food Workers
}

\author{
Asemptomatik Gıda Calışanlarında Cryptosporidium spp. 'nin Prevalansı
}

\section{Hanifi Körkoca1, Yaşar Göz', Ahmet Duran Ataş², Muhammet Güzel Kurtoğlư ${ }^{3}$ Kamil Ekici, Mustafa Berktaş ${ }^{5}$}

1Department of Nursing, School of Health Sciences, Muş Alparslan University, Muş, Turkey ${ }^{2}$ Department of Biology, Faculty of Arts and Sciences, Muş Alparslan University, Muş, Turkey ${ }^{3}$ Laboratory of Clinical Microbiology, Konya Research and Education Hospital, Konya, Turkey ${ }^{4}$ Department of Food Hygiene and Technology, Faculty of Veterinary Medicine, Yüzüncü Yıl University, Van, Turkey ${ }^{5}$ Department of Medical Microbiology, Faculty of Medicine, Yüzüncü Yıl University, Van, Turkey

\section{ABSTRACT}

Objective: Cryptosporidium spp. is obligatory intracellular parasite and causes intestinal infection. In intestine infections in the form of sporadic and epidemics, food and accordingly workers in food sector may play a role as the source of infection. In this study, it is aimed to reveal the existence of asymptomatic cryptosporidiosis.

Methods: In the study, stool samples of 393 workers -employed at various branches of food sector in the region of Van- are used. In order to detect Cryptosporidium spp. oocysts, Modified Ziehl Neelsen (MZN) Staining was used.

Results: In this study, asymptomatic cryptosporidiosis has been detected in 5 (1.27\%) of 393 workers.

Conclusion: Epidemiological findings indicate that food workers can be source of cryptosporidiosis outbreak. Thus, searching for the existence of asymptomatic cryptosporidiosis food workers -which epidemiologically has potential significance- and taking the required measures in case of its determination are significant in respect of public health. (Turkiye Parazitol Derg 2013; 37: 241-4)

Key Words: Asymptomatic cryptosporidiosis, food worker, Modified Ziehl Neelsen.

Received: 20.11.2012

Accepted: 20.10 .2013

\section{ÖZET}

Amaç: Cryptosporidium spp. zorunlu hücre içi parazit olup, bağırsak enfeksiyonuna neden olmaktadır. Sporadik ve salgınlar şeklinde neden olduğu barsak enfeksiyonlarında, gıdalar ve dolayısıyla gıda işçileri enfeksiyon kaynağı olarak rol oynayabilmektedir. Bu çalışmayla gıda işçilerinde asemptomatik kriptosporidiyozun varlığının ortaya konulması amaçlanmıştır.

Yöntemler: Çalışmada Van yöresinde gıda sektörünün çeşitli kollarında çalışan 393 işçiye ait dışkı örneği kullanıldı. Cryptosporidium spp. ookistlerinin tespiti için Modifiye Ziehl Neelsen (MZN) boyama yöntemi kullanıldı.

Bulgular: Çalışmada 393 gıda işçisinin 5'inde $(\% 1,27)$ asemptomatik kriptosporidiyoz tespit edilmiştir.

Sonuç: Epidemiyolojik ve moleküler bulgular gıda işçilerinin kriptosporidiyoz salgınının kaynağı olabileceğini göstermektedir. Bu nedenle epidemiyolojik açıdan potansiyel önemi olan gıda işçilerinde asemptomatik kriptosporidiyozun varlığının araştırılması ve tespiti halinde gerekli tetbirlerin alınması, halk sağlığı açısından önemlidir. (Turkiye Parazitol Derg 2013; 37: 241-4)

Anahtar Sözcükler: Asemptomatik kriptosporidiyoz, gıda işçisi, Modifiye Ziehl Neelsen.

Geliş Tarihi: 20.11.2012

Kabul Tarihi: 20.10.2013

This study was presented in $2^{\text {th }}$ National Veterinary Food Hygiene Congress 18-20 September 2006, İstanbul, Turkey.

Bu çalışma 2. Ulusal Veteriner Gıda Hijyeni Kongresi'nde sunulmuştur, 18-20 Eylül 2006, İstanbul, Türkiye.

Address for Correspondence / Yazışma Adresi: Hanifi Korkoca, PHD, Department of Nursing, School of Health Sciences, Muş Alparslan University, Muş, Turkey. Phone: +90 4322101614 E-mail: hkorkoca@hotmail.com

doi:10.5152/tpd.2013.2981 


\section{INTRODUCTION}

Cryptosporidium spp. is a protozoan enteric parasite which can cause gastroenteritis in human and animals (1). Cryptosporidium spp. has both sexual and asexual development and a complex life cycle also covering autoinfectious cycles and it has ability to complete its development in a single host (2).

Cryptosporidium spp. can contaminate directly by individuals, as a result of contact with animal or through the contamination of water by asymptomatic or symptomatic animals and humans carrying Cryptosporidium oocysts. In human living under insufficient sanitation conditions exposure to Cryptosporidium oocysts is more frequent (3). This parasite can survive for weeks to months in the environment. Moreover its infective dose is low (4).

While some infections of cryptosporidiosis are acute and self-limiting, others are chronic. With pathogenic types, the period and severity of infection is relevant to the immune status of the infected individual. While slight, mild or severe illness occurs in immunocompetent individuals, severe chronic infection or death may occur in immunocompromised individuals (5). As this organism has the potential to cause extended urgent medical care and even death, cryptosporidiosis outbreak has importance in respect of public health (6). Persistent asymptomatic oocysts shedding can prolong following the clinical infection (7).

Cryptosporidium spp. is among the parasitic protozoons relevant to food production (8). Moreover Cryptosporidium spp is indicated among the five most important emerging food-borne zoonotic pathogens by some authors (9). Workers in food sector can play a role in the cryptosporidiosis outbreak (6).

Modified Ziehl-Neelsen staining method is a technique widely used for staining of oocysts in fecal smears $(10,11)$.

In this study, it is aimed to reveal the existence of asymptomatic cryptosporidiosis in food workers.

\section{METHODS}

In our study stool samples of 393 asymptomatic workers in food sector-employed within the province Van and its surrounding with an average age of 29.3- were used.
In order to detect Cryptosporidium spp. oocysts Modified ZiehlNeelsen Staining method was used. With this aim a portion of stool samples were emulsified with formol-water containing $0.1 \%$ Tween 80 . And then fecal smears were prepared. Fecal smears were covered with concentrated methanol and kept for $3 \mathrm{~min}$. And then slides were covered with intense carbol-fuchsin and kept for $20 \mathrm{~min}$. Slides rinsed with slight tap water were decolorized for 15-30 sec in methanol containing $1 \% \mathrm{HCl}(\mathrm{v} / \mathrm{v})$ and then were rinsed with tap water. It was kept for $30 \mathrm{sec}$ in $0.4 \%$ malachite green as counterstain and rinsed with tap water. Slides dried by air were examined by $40 x$ objective lens, and in case of the detection of oocysts the existence of oocysts were verified byx100 oil-immersion objective lens (10).

\section{RESULTS}

In our study stool samples of 393 workers -365 male and 28 female- employed at different business lines (restaurant, catering, bakery, canteen, cafe, butcher, school refectory, hospital refectory, food market, delicatessen) in food sector were investigated for the detection of Cryptosporidium spp. oocysts. As a result of the examination of stool samples Cryptosporidium spp. oocysts were detected in 5 (1.27\%) samples of food workers one of whom was employed at hospital refectory, two at delicatessen and two at a butcher. The workers -in whom asymptomatic cryptosporidiosis was detected- were all male workers (Table 1).

\section{DISCUSSION}

Protozoon parasites can be transferred to food products through workers during the process of production (8). As Cryptosporidium does not multiply in food, food-borne cryptosporidiosis occurs via unhygienic food preparation, storage, preliminary preparation or food processing either through direct contamination by infected individuals during preparation or through fecal contamination of food (such as usage of contaminated water or biosolid, infected employee) (12)

Asymptomatic carriage can be significant and can cause person-to-person transmission (13). Chacin-Bonilla et al. (14) reported that they detected carriage at a rate of $60.6 \%$ in asymptomatic individuals among Indians of Venezuela. Park et al. (15)

Table 1. Prevalence of asymptomatic Cryptosporidium infection based on fecal oocyst detection in food workers by business lines

\begin{tabular}{|c|c|c|c|c|c|c|}
\hline \multirow[b]{2}{*}{ Business Lines } & \multicolumn{2}{|c|}{$\begin{array}{c}\text { Gender } \\
\text { (Male/Women) }\end{array}$} & \multicolumn{2}{|c|}{ Oocysts } & \multirow[b]{2}{*}{ Total } & \multirow{2}{*}{$\begin{array}{c}\text { Number of positive } \\
\text { specimens ( } \% \text { positive }\end{array}$} \\
\hline & $M$ & $\mathbf{W}$ & $M(+/-)$ & W (+/-) & & \\
\hline Restaurant & 125 & 4 & $0 / 125$ & $0 / 4$ & 129 & 0 \\
\hline Catering & 49 & 1 & $0 / 49$ & $0 / 1$ & 50 & 0 \\
\hline Bakery & 45 & 3 & $0 / 45$ & $0 / 3$ & 48 & 0 \\
\hline Canteen, Cafe & 43 & 0 & $0 / 43$ & $0 / 0$ & 43 & 0 \\
\hline Butcher & 35 & 0 & $2 / 33$ & $0 / 0$ & 35 & 5.71 \\
\hline School Refectory & 20 & 4 & $0 / 20$ & $0 / 4$ & 24 & 0 \\
\hline Food Market & 17 & 8 & $0 / 17$ & $0 / 8$ & 25 & 0 \\
\hline Hospital Refectory & 16 & 1 & $1 / 15$ & $0 / 1$ & 17 & 5.88 \\
\hline Delicatessen & 15 & 7 & $2 / 13$ & $0 / 7$ & 22 & 9.09 \\
\hline Total & 365 & 28 & $5 / 360$ & $0 / 28$ & 393 & 1.27 \\
\hline
\end{tabular}




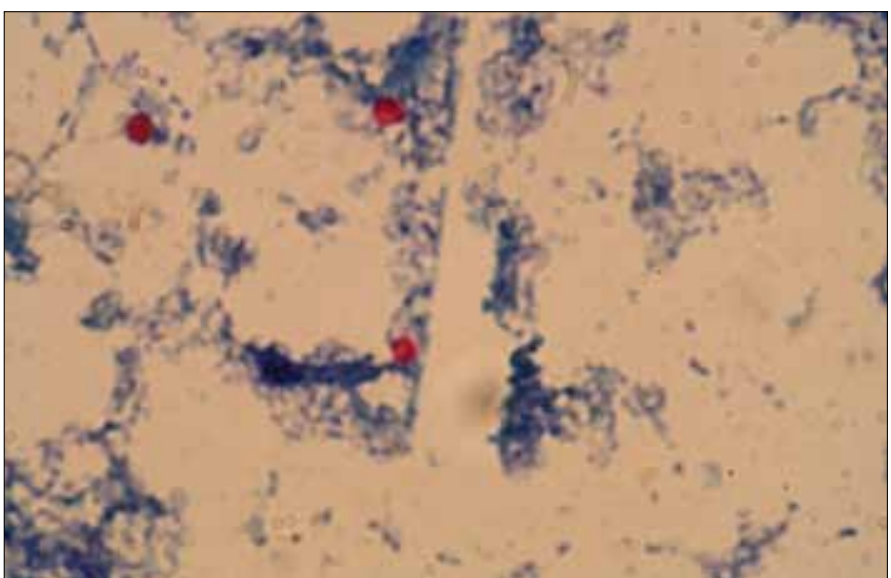

Figure 1. Modified Ziehl Neelsen stained slide showing three Cryptosporidium oocysts

in a study administered on individuals living in 25 different islands in Korea, detected Cryptosporidium spp. oocysts at a rate of $1.5 \%$. Hörman et al. (16) informed that as a result of meta analysis studies, they estimated the rate of asymptomatic cryptosporidiosis prevalence in Scandinavian countries as $0.99 \%$. In a study conducted in our country, positivity rate was detected as $3.1 \%$ in asymptomatic family members in the province of Mersin (17). However, in Sivas center, 6.2\% Cryptosporidium antigen was detected in asymptomatic people (18).

In other studies conducted in our country regarding asymptomatic children, Otağ et al. (19) informed that they detected oocysts as of $5.5 \%$ and Akyön et al. (20) reported as $3.5 \%$ in children having diarrhea and that they could not determine oocyst in control group.

In Thailand it was reported that Cryptosporidium oocyst was detected as $0.3-12 \%$ in asymptomatic children (21). Oocyst was detected in asymptomatic children as $2.3 \%$ by Palit et al. (22), $24.17 \%$ by Okafor and Okunji (23), 3\% by Reinthaler et al. (24), 6.4\% by Pettoello-Mantovani et al. (25), 4.7\% Al Braiken et al. (26) and $31.6 \%$ by Esteban et al. (27). While Freites et al. (28) informed that they detected oocyst as $11.8 \%$ in workers at food sector in Venezuela, Adam et al. (29) informed that they did not detect Cryptosporidium oocyst in the stools of asymptomatic workers employed in food sector and asymptomatic children.

The rate detected in our study (1.27\%) was found to be in good agreement with the rate (1.5\%) obtained by the studies of Park et al. (15). A difference from the positivity rates obtained by other studies was detected. This difference may arise from different methods employed (5, 30), geographical (9), seasonal $(9,31-34)$ or age related differences.

Food workers employed in food production and catering services can play a role as a means in contaminating the products (35).

Pönka et al. (36) -in their first reports regarding an food-borne outbreak in Finland due to C. parvum- reported that stools samples were obtained from 12 of 72 individuals with diarrhea who dined at the same canteen and got sick, and that C. parvum was detected in four of these samples. The same researchers informed that they suspected of salad mixture as the source of outbreak and that the workers employed in food sector should be aware of the requirements for the appropriately prepared vegetables as to prevent contamination.

Quiroz et al. (6) as a result of the DNA analysis of Cryptosporidium isolates obtained from outbreak, reported that the possible source of the outbreak was an ill foodhandler. Moreover foodborne cryptosporidiosis outbreak due to fresh apple juice, non pasteurized milk, chicken salad, uncooked onion, fresh vegetable and fruit prepared by an infected cook was reported (37). While an effective drug for treatment and prophylaxis was not available until recently (5), nitazoxanide was licensed for the treatment of all age groups in the USA (12).

\section{CONCLUSION}

In the control of infection, the infection control measures are the basis, however, it has been informed that nitazoxanide can be used to control the outbreaks since the antimicrobial treatment may have potential contribution. Moreover the requirement for extensive studies regarding the parasitological and clinical effectiveness of nitazoxanide has been indicated (38). Schlundt et al. (9) emphasized the significance of scientific programs intended to decrease pathogens constantly at relevant points of food production chain. Presently, there is much debate with regard to the management of Cryptosporidium-positive food handlers within the food processing sector. Within this scope, for the prevention of contamination due to food workers, the screening stool specimens of personnel is suggested (35). Moreover it is also suggested that the food workers thoroughly wash their hands before handling food items and utensils and not contact cooked food, uncooked vegetables and fruits with bare hands that the kitchen surfaces be thoroughly washed between each preparation and that staff with gastroenteritis not be employed during their illnesses (39).

The existence of asymptomatic cryptosporidiosis in food workers who pose a potential epidemiological significance in respect for cryptosporidiosis-is revealed in this study.

Conflict of Interest: No conflict of interest was declared by the authors.

Financial Disclosure: The authors declared that this study has received no financial support.

Peer-review: Externally peer-reviewed.

Ethics Commitee Approval: The study was conducted in 2006 and an ethics commitee approval was not received.

Informed Consent: The study was conducted in 2006 and an informed consent was not obtained.

Author Contributions: Concept - H.K.; Design - H.K.; Supervision - H.K., Y.G.; Funding - H.K ; Materials - H.K.; Data Collection and/or Processing - H.K.,Y.G.; Analysis and/or Interpretation H.K.,Y.G.; Literature Review - H.K., A.D.A.; Writing - H.K., A.D.A.; Critical Review - Y.G., M.B., M.G.K.,K.E.; Other - M.B., M.G.K.,K.E. 
Çıkar Çatışması: Yazarlar çıkar çatışması bildirmemişlerdir.

Finansal Destek: Yazarlar bu çalışma için finansal destek almadıklarını beyan etmişlerdir.

Hakem değerlendirmesi: Dış bağımsız.

Etik Komite Onayı: Çalışmamız 2006 tarihinde gerçekleştirilmiş olup etik komite onayı alınmamıştır.

Hasta Onamı: Çalışmamı 2006 tarihinde gerçekleştirilmiş olup hasta onamı alınmamıştır.

Yazar Katkıları: Fikir - H.K.; Tasarım - H.K.; Denetleme - H.K., Y.G.; Kaynaklar - H.K.; Malzemeler - H.K.; Veri toplanması ve/veya işlemesi - H.K., Y.G.; Analiz ve/veya yorum - H.K., Y.G.; Literatür taraması - H.K., A.D.A.; Yazıyı yazan - H.K., A.D.A.; Eleştirel inceleme - Y.G., M.B., M.G.K., K.E; Diğer - M.B., M.G.K., K.E.

\section{REFERENCES}

1. Morgan UM, Xiao L, Fayer R, Lal AA, Thompson RC. Variation in Cryptosporidium: towards a taxonomic revision of the genus. Int $J$ Parasitol 1999; 29: 1733-51. [CrossRef]

2. Keusch GT, Hamer D, Joe A, Kelley M, Griffiths J, Ward H. Cryptosporidia-who is at risk?. Schweiz Med Wochenschr 1995; 125 : 899-908.

3. Gonçalves EMN, Silva AJ, Paulo MBP, Uemura H, Moura INS, Castilho VLP, et al. Multilocus genotyping of Cryptosporidium hominis associated with diarrhea outbreak in a day care unit in Sao Paulo. Clinics 2006; 61: 119-26. [CrossRef]

4. Caccio SM. New methods for the diagnosis of Cryptosporidium and Giardia. Parassitologia 2004; 46: 151-55.

5. Fayer R, Xiao L. Cryptosporidium and Cryptosporidiosis. Second Edition. Boca Raton: CRC Press Taylor \& Francis Group 2008.

6. Quiroz ES, Bern C, MacArthur JR, Xiao L, Fletcher M, Arrowood MJ, et al. An outbreak of cryptosporidiosis linked to a foodhandler. $J$ Infect Dis 2000; 181: 695-700. [CrossRef]

7. Stehr-Green JK, McCaig L, Remsen HM, Rains CS, Fox M, Juranek DD. Shedding of oocysts in immunocompetent individuals infected with Cryptosporidium. Am J Trop Med Hyg 1987; 36: 338-42.

8. Dawson D. Foodborne protozoan parasites. Int J Food Microbiol 2005; 103: 207-27. [CrossRef]

9. Schlundt J, Toyofuku H, Jansen J, Herbst SA. Emerging food-borne zoonoses. Rev Sci Tech 2004; 23: 513-33.

10. Casemore DP. Laboratory methods for diagnosing cryptosporidiosis. J Clin Pathol 1991; 44: 445-51. [CrossRef]

11. Insulander M, de Jong B, Svenungsson B. A food-borne outbreak of cryptosporidiosis among guests and staff at a hotel restaurant in Stockholm county, Sweden, September 2008. Euro Surveill 2008; 13: pii:19071.

12. Yoder JS, Beach MJ. Cryptosporidium surveillance and risk factors in the United States. Exp Parasitol 2010; 124: 31-39. [CrossRef]

13. Balatbat $A B$, Jordan GW, Tang YJ, Silva, J. Detection of Cryptosporidium parvum DNA in Human Feces by Nested PCR. J Clin Microbiol 1996; 34: 1769-72.

14. Chacin-Bonilla L, Mejia De Young M, Cano G, Guanipa N, Estevez $\mathrm{J}$, Bonilla E. Cryptosporidium infections in a suburban community in Maracaibo, Venezuela. Am J Trop Med Hyg 1993; 49: 63-7.

15. Park JH, Kim HJ, Guk SM, Shin EH, Kim JL, Rim HJ, et al. A survey of cryptosporidiosis among 2,541 residents of 25 coastal islands in Jeollanam-do (Province), Republic of Korea. Korean J Parasitol 2006; 44: 367-72. [CrossRef]

16. Hörman A, Korpela H, Sutinen J, Wedel H, Hänninen M-L. Metaanalysis in assessment of the prevalence and annual incidence of Giardia spp. and Cryptosporidium spp. infections in humans in the Nordic countries. Int J Parasitol 2004; 34: 1337-46. [CrossRef]

17. Börekçi G, Otağ F, Emekdaş G. Mersin'de bir gecekondu mahallesinde yaşayan ailelerde Cryptosporidium prevalansı. Infeksiyon Derg 2005; 19: 39-46.
18. Özçelik S, Poyraz Ö, Kalkan K, Malatyalı E, Değerli S. Hayvancılıkla uğraşanlarda ve sığırlarda Cryptosporidium spp. yaygınlığının ELISA ile araştırılması. Kafkas Univ Vet Fak Derg 2012; A61-A64.

19. Otağ F, Aslan G, Emekdaş G, Aydın E, Özkan AT, Çeber K. Mersin ilinde ilkokul öğrencilerinde Cryptosporidium spp. ookistlerinin araştırılması. Türkiye Parazitol Derg 2007; 31: 17-19.

20. Akyön Y, Ergüven S, Arikan S, Yurdakök K, Günalp A. Cryptosporidium parvum prevalence in a group of Turkish children. Turk J Pediatr 1999; 41: 189-96.

21. Wongstitwilairoong $B$, Srijan A, Serichantalergs $O$, Fukuda CD, Mcdaniel P, Bodhidatta L, et al. Intestinal parasitic infections among pre-school children in Sangkhlaburi, Thailand. Am J Trop Med Hyg 2007: 76: 345-50.

22. Palit A, Sur D, MitraDhar K, Saha MR. Asymptomatic cryptosporiosis in a periurban slum setting in Kolkata, India-a pilot study. Jpn J Infect Dis 2005; 58: 110-11.

23. Okafor JI, Okunji PO. Prevalence of Cryptosporidium oocysts in faecal samples of some school children in Enugu State, Nigeria. J Commun Dis 1996; 28: 49-55.

24. Reinthaler FF, Mascher F, SixI W, Enayat U, Marth E. Cryptosporidiosis in children in Idukki district in southern India. J Diarrhoeal Dis Res 1989; 7: 89-91.

25. Pettoello-Mantovani M, Di Martino L, Dettori G, Vajro P, Scotti S, Ditullio MT, et al. Asymptomatic carriage of intestinal Cryptosporidium in immunocompetent and immunodeficient children: a prospective study. Pediatr Infect Dis J 1995; 14: 1042-47. [CrossRef]

26. Al Braiken FA, Amin A, Beeching NJ, Hommel M, Hart CA. Detection of Cryptosporidium amongst diarrhoeic and asymptomatic children in Jeddah, Saudi Arabia. Ann Trop Med Parasit 2003; 97: 505-10. [CrossRef]

27. Esteban JG, Aguirre C, Flores A, Strauss W, Angles R, Mas-Coma S. High Cryptosporidium prevalences in healthy aymara children from the Northern Bolivian Altiplano. Am J Trop Med Hyg 1998; 58: 50-55.

28. Freites A, Colmenares D, Pérez M, García M, Díaz de Suárez O. Cryptosporidium sp infections and other intestinal parasites in food handlers from Zulia state, Venezuela. Invest Clin 2009; 50: 13-21.

29. Adam AA, Hassan HS, Shears P, Elshibly E. Cryptosporidium in Khartoum, Sudan. East Afr Med J 1994; 71: 745-46.

30. Sakarya Y, Kar S, Tanyüksel M, Karaer Z, Babur C, Vatansever Z. Detection of Cryptosporidium spp. in humans and calves through nested PCR and carbol fuchsin staining methods in Ankara, Turkey. Kafkas Univ Vet Fak Derg 2012; 18: 531-36.

31. Laupland KB, Church DL. Population-based laboratory surveillance for Giardia sp. and Cryptosporidium spp. infections in a large Canadian health region. BMC Infect Dis 2005; 5: 72. [CrossRef]

32. Learmonth JJ, lonas G, Pita AB, Cowie RS. Identification and genetic characterisation of Giardia and Cryptosporidium strains in humans and dairy cattle in the Waikato Region of New Zealand. Water Sci Technol 2003; 47: 21-26.

33. Krause W, Abraham A, Lehmann D. Evidence of Cryptosporidium in children with symptomatic enteritis from the Leipzig administrative area 1987-1992. Appl Parasitol 1995; 36: 66-71.

34. Hlavsa MC, Watson JC, Beach MJ. Cryptosporidiosis surveillance United States 1999-2002. MMWR 2005; 54: 1-8.

35. Millar BC, Finn M, Xiao L, Lowery CJ, Dooley JSG, Moore JE. Cryptosporidium in foodstuffs-an emerging aetiological route of human foodborne ilness. Trends Food Sci Tech 2002; 13: 168-87. [CrossRef]

36. Pönka $A$, Kotilainen $H$, Rimhanen-Finne $R$, Hokkanen $P$, Hänninen ML, Kaarna A, et al. A foodborne outbreak due to Cryptosporidium parvum in Helsinki, November 2008. Euro Surveill 2009; 14: 19269.

37. Dillingham RA, Lima AA, Guerrant RL. Cryptosporidiosis: epidemiology and impact. Microbes Infect 2002; 4: 1059-66. [CrossRef]

38. Vandenberg O, Robberecht F, Dauby N, Moens C, Talabani H, Dupont $\mathrm{E}$, et al. Management of a Cryptosporidium hominis outbreak in a day-care center. Pediatr Infect Dis J 2012; 31: 10-15. [CrossRef]

39. Fayer R, Morgan U, Upton SJ. Epidemiology of Cryptosporidium: transmission, detection and identification. Int J Parasitol 2000; 30: 1305-22. [CrossRef] 